\title{
KONSELING ANAK BERDASARKAN MATIUS 18: 10 DAN RELEVANSINYA UNTUK MENINGKATKAN SPIRITUAL ANAK SEKOLAH MINGGU
}

\author{
Yuhana Yunus ${ }^{1 *}$ \\ ${ }^{1}$ Sekolah Tinggi Teologi Excelsius \\ *Email: rendyana707@gmail.com \\ CHILD COUNSELING BASED ON MATTHEW 18:10 AND ITS RELEVANCE FOR \\ IMPROVING THE SPIRITUAL OF SUNDAY SCHOOL CHILDREN
}

\begin{abstract}
One of the church's tasks is the maintenance of the congregation, among others through counseling ministry, however, the counseling referred to here is not only carried out for adults but also for children or Sunday school children who are the forerunners or the next generation of the church. That means the church, servants of God, elders, councils, teachers and parents should be involved in this ministry. Counseling is a reciprocal relationship between two individuals, namely the counselor and the counselee (the person being served/guided) who need understanding to overcome the problems faced by the client. The research method that the author uses is a descriptive writing method with a literature review approach and field data collection through interviews. Conclusion: child counseling based on Matthew 18:10 and its relevance to spiritually Sunday school children improvement are priorities, that children are precious in the eyes of God because they should not be despised, humiliated or even neglected, second, angels care about children, third, children's guidance that centered to the father.
\end{abstract}

\section{Key Words: Counseling, child spiritual}

\begin{abstract}
Abstrak: Salah satu tugas gereja ialah pemeliharaan terhadap jemaat antara lain melalui pelayanan konseling, namun demikian konseling yang dimaksudkan disini bukan hanya dilakukan terhadap orang dewasa tetapi juga terhadap anak atau anak Sekolah Minggu yang merupakan cikal bakal atau generasi penerus dari gereja tersebut. Itu berarti gereja, hamba Tuhan, penatua, majelis, guru maupun orang tua hendaknya terlibat dalam pelayanan ini. Konseling adalah hubungan timbal balik antara dua individu, yaitu konselor dan konsele (orang yang dilayani/dibimbing) yang membutuhkan pengertian untuk mengatasi persoalan yang dihadapi oleh klien. Metode penelitian yang penulis gunakan adalah metode penulisan deskriptif pendekatan kajian literatur dan pengumpulan data lapangan melalui wawancara. Kesimpulan: konseling anak berdasarkan Matius 18:10 dan relevansinya untuk meningkatkan spiritual anak sekolah minggu adalah: pertama, bahwa anak berharga di mata Tuhan karena itu tidak boleh direndahkan, dihina bahkan diabaikan, kedua, malaikat-malaikat memperdulikan Anak-anak, ketiga, bimbingan Anak berpusat kepada Bapa.
\end{abstract}

Kata Kunci: Konseling, spiritual anak

\section{PENDAHULUAN}

Konseling dianggap sebagai layanan yang paling utama dalam pelaksanaan fungsi pengentasan masalah klien. ${ }^{1} \quad$ Konseling mempunyai proses konselor (hamba Tuhan di gereja atau guru di Sekolah) di mana guru bukan lagi menjadi polisi sekolah, sebaliknya

${ }^{1}$ Prayitno dan Erman Amti, Dasar-dasar Bimbingan dan Konseling (Jakarta: Rineka Cipta, 2015), 288-289. mereka bisa menjadi orang terdekat yang mungkin bisa membantu mengentaskan anak didik dari rumitnya permasalahan yang mereka hadapi. ${ }^{2}$ Konseling mempunyai peranan penting karena selalu mendamping anak-anak dalam sekolah persoalan yang ia hadapi untuk berkembang.

${ }^{2}$ Lativani Rahmania, Wajah Baru Bimbingan Konseling di Era Postmodern, diakses 24 Mei 2021, www.kompasiana.com>humaniora>edukasi. Jurnal Excelsis Deo: Jurnal Teologi, Misiologi dan Pendidikan | 87 
Konseling anak menekan pada anak dalam usia dini, 5-7 tahun berada di dalam masa golden age dimana fungsi kognitif otak dan psikis dalam kondisi yang sangat prima. Kemampuan anak menyelesaikan masalah dalam usia 5-12 tahun akan sangatlah penting untuk membekali anak menghadapi dan menyelesaikan masalah dalam fase remaja dan juga dewasa. Sebaliknya kegagalan anak dalam kemampuannya menyelesaikan masalah di usia dini akan sangat berdampak panjang dalam kemampuan anak itu menghadapi berbagai masalah, hingga remaja bahkan dewasa. Karena itulah tidak heran, kita melihat banyak orang yang sudah dewasa secara usia namun sangat tidak mampu deal dan menemukan solusi dalam masalah-masalah hidupnya. Hal itu semua disebabkan gagalnya pencapaian berbagai hal yang harus dihadapi anak dalam periode golden age tersebut. ${ }^{3}$

Konseling sendiri bukanlah merupakan suatu disiplin ilmu seperti halnya ilmu kedokteran gigi atau kedokteran umum yang pada dasarnya bergantung kepada pengetahuan teknis dan dijelaskan oleh seorang professional dengan benar dan terlatih. Peranan konseling diperlukan dalam semua ini kehidupan karena bersinggungan langsung dengan pribadi manusia atau orang yang memerlukan pelayanan konseling (konseli). Dalam hal ini pelayanan konseling yang benar mau menghasilkan suatu proses pembebasan adalah pelayanan yang berhubungan dengan soal-soal konkrit dari hidup manusia. Konseling adalah hubungan timbal balik antara dua individu, yaitu konselor dan konsele (orang yang dilayani/dibimbing) yang membutuhkan pengertian untuk mengatasi persoalan yang dihadapinya. ${ }^{4}$ Dengan demikian proses konseling memungkinkan adanya keterbukaan

${ }^{3}$ Kay Therisnajaya, Konseling Anak, diakses 24, Mei, 2021, https://www.konselinganak.com/.

${ }^{4}$ Gary R. Collins, Pengantar Pelayanan Konseling Kristen yang Efektif (Malang: Seminari Alkitab Asia Tenggara, 1990), 8-9. antara kedua pihak secara khusus dari pihak orang yang dikonseling (konsele). Jika gereja yang merupakan lembaga pelayanan memberi perhatian terhadap persoalan anak, maka gereja sebagai lembaga rohani hendaknya memainkan peranannya dalam upaya memberikan pendampingan terhadap anak tentu melalui pelayanan konseling.

Melihat fenomena ini, gereja sebagai lembaga persekutuan hendaknya memainkan peranan yang lebih luas dalam masyarakat khususnya bagi dan atau terhadap persoalanpersoalan hidup manusia. Hal ini tentu sejalan dengan tugas dan panggilan termasuk ajaran gereja sebagaimana yang diungkapkan Render dalam bukunya dengan mengutip pernyataan Harianto bahwa gereja sebagai Tubuh Kristus dan sebagai sarana kesaksian dimana untuk mencapai pelayanan tersebut terkait dengan tugas pelayanan gereja yang meliputi koinonia (persekutuan), marturia (kesaksian) dan diakonia (pelayanan). ${ }^{5}$ Sebagaimana diketahui bahwa setiap manusia baik anak-anak hingga orang tua tidak pernah lepas dari yang namanya masalah, baik dalam hidup pribadi, keluarga maupun dalam hidup berkelompok sehingga dapat membuat seseorang mengalami depresi dan putus asa. Karena disamping hidup rohaninya tidak berkembang ke arah kedewasaan, juga bisa berakibat fatal dengan cara mengakhiri hidup seperti bunuh diri dan sebagainya. Dalam suasana seperti ini pelayanan konseling sangat dibutuhkan untuk membantu mencari jalan keluar dari permasalahan yang mereka hadapi.

Lebih detail lagi bahwa ditemukan fenomena di lapangan dimana gereja sebagai wadah pembinaan anak-anak sekolah Minggu yang hanya dilakukan seminggu sekali, sementara gaya hidup anak-anak lebih

${ }^{5}$ Render Bin Luwis, Pembinaan Spiritual Jemaat Gereja (Bandung: Agiamedia, 2021), 2; Harianto GP, Teologi Pastoral (Yogyakarta: Andi, 2020), 56. 
dipengaruhi oleh game atau berbagai permainan di Hand Phone (HP). Walaupun demikian gereja ini secara tubuh Kristus selalu diperhadapkan dengan berbagai tantangan. Tantangan itu dari berbagai segi yakni dari dalam gereja sendiri, tetapi juga dari luar jemaat secara sekular. John Stott menuliskan dalam bukunya bahwa "Pada awal abad ke 21, kita diperhadapkan dengan berbagai tantangan yang membingungkan yang tidak pernah terbayangkan pada lima puluh tahun yang lalu". ${ }^{6} \quad$ Itu berarti orang kristen harus melibatkan diri dan berusaha sungguhsungguh untuk berpikir secara Kristiani dalam menghadapi berbagai tantangan yang sedang dihadapi gereja baik secara individu maupun secara kolektif, baik orang dewasa maupun anak-anak

Peneliti akan mencari jawaban dari beberapa pertanyan berikut: Apakah yang dimaksud dengan konseling anak berdasarkan Matius 18:10? Bagaimanakah keadaan Spiritual Anak Sekolah Minggu? Bagaimanakah relevansi konseling anak Berdasarkan Matius 18: 10 untuk meningkatkan Spiritual Anak Sekolah Minggu?

\section{METODE}

Penelitian ini menggunakan penelitian deskriptif yakni metode yang dipakai untuk meneliti sekelompok manusia, suatu objek, suatu kondisi, sistem pemikiran ataupun suatu kelas peristiwa-peristiwa pada masa sekarang. ${ }^{7}$ Nazir juga mengutip pandangan Whitney bahwa metode penelitian deskriptif adalah suatu metode pencarian fakta dengan interpretasi yang tepat. ${ }^{8}$ Dengan demikian metode ini untuk mendeskripsikan data dari berbagai literatur dan hasil dari suatu

\footnotetext{
${ }^{6} \mathrm{John}$ Stott, Isu-isu Global (Jakarta: Yayasan Komunikasi Bina Kasih, 2015), 17.

${ }^{7}$ Nazir Mohamad, Metode Penelitian (Jakarta: Ghalia Indonesia, 1988), 63.

${ }^{8}$ Ibid.
}

penelitian yang diperlukan dalam penulisan topik yang ada. Metode penelitian yang penulis gunakan adalah metode penulisan deskriptif pendekatan kajian literatur dan pengumpulan data lapangan melalui wawancara.

\section{PEMBAHASAN}

Berkaitan dengan topik yang dibahas, maka dalam bagian ini ada beberapa point yang akan peneliti paparkan, diantaranya: pengertian konseling anak, keadaan spiritual anak sekolah minggu serta relevansi konseling anak berdasarkan Matius 18:10 untuk meningkatkan spiritual anak sekolah minggu.

\section{Pengertian Konseling Anak berdasarkan Matius 18:10}

Kata "konseling" dalam bahasa Inggris consul artinya: wakil; counsult artinya minta nasehat, berunding dengan; console artinya menghibur dan consolide artinya menguatkan. Bisa diartikan kata konseling adalah kegiatan seseorang yang menguatkan, menghibur yang dimintakan nasehat dan berunding dengan seseorang. ${ }^{9}$ Jadi pelayanan konseling artinya hamba Tuhan (pendeta, penginjil, aktivis gereja, guru dan lain-lain) yang memberikan nasehat, penghiburan dan penguatan bagi jemaatnya atau sesama orang percaya lainnya.

Pelayanan konseling mempunyai sifat pertemuan yaitu: antara hamba Tuhan (konselor) dan orang yang membutuhkan bantuan atau pelayanannya dan pertemuan antara mereka berdua (konselor dan konsele) dengan Allah yang memimpin dan memberi isi pada pertemuan tersebut. Pengistilahan ini dihubungan dengan diri Yesus Kristus dan

\footnotetext{
${ }^{9}$ Agustina Pasang, "Konseling dan Pelayanan Konseling”, Materi Seminar GMII Filadelfia Balikpapan, (2012), 1-2.
} Jurnal Excelsis Deo: Jurnal Teologi, Misiologi dan Pendidikan | 89 
karya-Nya sebagai Pastor sejati yang baik (Yoh 10). Ungkapan ini menunjuk pada pelayanan Yesus Kristus yang tanpa pamrih, bersedia memberi pertolongan terhadap pengikut-Nya. Sehingga tugas ini bukan hanya tugas pendeta, hamba Tuhan saja tetapi tugas bagi setiap orang percaya termasuk guru. ${ }^{10}$ Sedangkan istilah konseling sendiri berasal dari bahasa Latin "Consillium" yang berarti dengan atau bersama dan mengambil atau memegang. Memberi pengertian bahwa ada sesuatu yang harus dipegang, diambil bersama-sama, ${ }^{11}$ tentu menyangkut hubungan timbal balik antara konseli dan konselor.

Lebih jauh mengenai pengertian konseling, Oates menjelaskan bahwa konseling merupakan suatu disiplin ilmu non medis yang memiliki sasaran untuk memberi fasilitas dan menimbulkan pertumbuhan serta perkembangan kepribadian, menolong pribadipribadi untuk mengubah pola-pola kehidupan yang menyebabkan mereka mengalami kehidupan yang tidak berbahagia. Selain itu menyediakan suasana persaudaraan dan kebijaksanaan bagi pribadi-pribadi yang sedang menghadapi kehilangan dan kekecewaan dalam kehidupan yang tidak dapat dihindari. ${ }^{12}$ Senada dengan hal ini Carl Rogers, seorang psikolog humanistik terkemuka, memiliki pandangan bahwa konseling merupakan hubungan terapi dengan klien dengan tujuan untuk melakukan perubahan self (diri sendiri) pada klien. Rogers menegaskan konseling sebagai "the process by which structure of the self is relaxed in the safety of relationship with the therapist and previously denied experiences are preceived an then

\footnotetext{
${ }^{10}$ Aart van Beek, Pendampingan Pastoral (Jakarta: BPK Gunung Mulia, 2007), 10.

${ }^{11}$ Kristina Tjandrarini, Bimbingan Konseling Keluarga (Salatiga: Widya Sari Press, 2004), 5-6.

${ }^{12}$ Wayne E. Oates, Pastoral Counseling (Philadelfia: The Westminster Press, 1974), 9.

${ }^{13}$ Latipun, Psikologi Konseling (Malang: UMM Press, 2015), 3.
}

integrated in to an altered self," 13 hal ini berarti bahwa tujuan konseling menekankan pada perubahan sistem self klien dari akibat hubungan diantara kedua belah pihak yakni konselor dan konseli/klien. Dengan demikian dapat dipahami bahwa konseling merupakan suatu pelayanan yang penting untuk dilakukan oleh gereja-gereja baik terhadap orang dewasa maupun anak-anak, terlepas dari masalahmasalah kehidupan dan atau masalah-masalah sosial yang mereka alami. Sebagaimana ditegaskan oleh Thantawy $\mathrm{R}$ dimana konseling yang adalah hubungan timbal balik diantara dua orang individu, menunjuk pada konselor yang berupaya menolong konseli/klien sehingga mampu mengatasi masalah/problema yang sedang dihadapinya. $^{14}$

Dalam Perjanjian Lama, istilah konseling salah satunya terdapat dalam 1 Tawarikh 27:32 "soferim" dalam bahasa Inggris diterjemahkan "counselor" artinya "penasihat" istilah ini juga muncul dalam Yesaya 9:6 "misera" sehubungan dengan kedatangan Yesus sebagai Penasehat ajaib. ${ }^{15}$ Sementara dalam Perjanjian Baru, istilah konselor (counselor) sering kali muncul dalam hubungan dengan Roh Kudus (parakletos) yang dalam bahasa Indonesia diterjemahkan sebagai penghibur, penasihat, penolong. ${ }^{16}$ Sehingga konseling juga dapat dipahami sebagai tindakan yang dihubungkan dengan pekerjaan Roh Kudus, atau dengan kata lain konseling tidak hanya melibatkan dua orang (konselor dan konseli) tetapi juga melibatkan Allah karena hanya kepada Dialah kita datang meminta pertolongan.

\footnotetext{
${ }^{14}$ Thantawy R., Kamus Istilah Bimbingan dan Konseling (Jakarta: Gramedia, 2005), 56.

${ }^{15}$ Agustina Pasang, "Konseling dan Pelayanan Konseling", Materi Seminar GMII Filadelfia Balikpapan, 2.

${ }^{16}$ E.P. Ginting, Gembala dan Konseling Pastoral (Yogyakarta: Andi, 2002), 2.
} 
Dalam hubungannya dengan anakanak, Kathryn Geldard menjelaskan konseling anak adalah konseling terhadap anak yang melibatkan konselor dimana anak bisa berbicara bebas mengenai masalah yang mereka hadapi, disini tentunya konselor juga memerlukan kemampuan konseling verbal dalam menghubungkan dengan strategi lain, misalnya konselor bergabung dengan anak melalui permainan, atau pun menggunakan media dan sebagainya. ${ }^{17}$ Meski demikian, keterlibatan Allah dalam proses konseling tentu merupakan hal yang sangat penting dimana peranan Tuhan Yesus sebagai Penasehat Ajaib menunjukkan bahwa manusia terbatas dalam menjalankan fungsi atau tugasnya sekalipun sebagai konselor ia dapat membantu konseli menemukan akar persoalannya tapi tidak ada manusia yang dapat menyediakan kasih karunia untuk mengatasi kebiasaan-kebiasaan yang salah (dosa). Manusia membutuhkan kasih Allah dan Allah sudah siapkan sarana untuk dimintakan pertolongan bagi setiap orang yang membutuhkannya, yaitu Alkitab. Jadi pelayanan konseling pertama-tama adalah rekonsiliasi/pendamaian (2 Kor. 5:20). Alkitab sebagai dasar theology dalam pelayanan konseling dipakai sebagai acuan yang tidak bisa ditawar-tawar lagi.

Psikologis dari istilah Yunani "psyche" artinya jiwa, "logos" artinya ilmu atau pengetahuan atau ilmu pengetahuan tentang jiwa. Psikologi adalah ilmu yang mempelajari tingkah laku manusia atau jiwa manusia dan tergolong suatu bidang sains. ${ }^{18}$ Wikipedia menuliskan pengertian psikologi sebagai salah satu bidang ilmu pengetahuan dan ilmu terapan yang mempelajari tentang perilaku, fungsi

\footnotetext{
${ }^{17}$ Kathryn Geldard, Konseling Anak-anak Panduang Praktis (Yogyakarta: Pustaka Pelajar, 2011), 3.

${ }^{18}$ Agustina Pasang, "Konseling dan Pelayanan
} Konseling", Materi Seminar GMII Filadelfia Balikpapan, 2-3. mental dan proses manusia melalui praktik psikologis. ${ }^{19}$ Adnan mendefinisikan Psikologi sebagai ilmu pengetahuan yang mempelajari semua tingkah laku individu yang tidak dapat dilepaskan dari proses lingkungan dan yang terjadi dalam diri individu tersebut, apa yang terjadi dalam diri pribadi tersebut dapat disebut sebagai proses mental. ${ }^{20}$ Dengan demikian dapat disimpulkan bahwa psikologi adalah suatu sains yang berdasarkan penelitian yang nyata dan benar sehingga nilai-nilai yang tidak bisa dijangkau oleh indra manusia tidak bisa dimasukkan sebagai kategori psikologis., Seorang psikolog seringkali mengambil keputusan untuk memberi jalan keluar bagi orang yang dikonselingnya hanya berdasarkan pada konsepsi manusia psikolog itu sendiri. Kalau seseorang pergi konseling pada dua orang psikolog pasti ada dua pendapat yang berlainan dan ini sangat mengganggu, karena psikologi sekuler hanya memandang manusia sebagai mahkluk jasmani dan ini bertentangan dengan Firman Tuhan karena manusia bukan hanya mahkluk jasmani tapi juga mahkluk rohani. Ada nilai-nilai rohani yang terabaikan oleh psikologi.

Lebih dalam lagi mengenai Konseling Anak berdasarkan Matius 18:10 adalah: "Ingatlah, jangan menganggap rendah seorang dari anak-anak kecil ini. Karena Aku berkata kepadamu: Ada malaikat mereka di sorga yang selalu memandang wajah Bapa-Ku yang di sorga" (Mat. 18:10). Teks tersebut menekankan pada beberapa pengetian sebagai berikut;

\section{Anak Berharga di Mata Tuhan}

"Jangan menganggap rendah seorang

\footnotetext{
19"'Psikologi," diakses 16 april 2021, https://id.wikipedia.org/wiki/Psikologi.

${ }^{20}$ Adnan Achiruddin Saleh, Pengantar Psikologi (Makasar: Aksara Timur, 2018), 8.
} 
dari anak-anak kecil ini”, kata rendah (kataphroneo) berarti menghina atau mengabaikan. ${ }^{21}$ Sementara kata anak yang kecil (mikros) dapat berarti kecil, sedikit, sebentar, muda. kecil menunjuk pada kuantitas, ukuran, tingkat, kedudukan atau usia. $^{22}$ Dengan demikian kata anak-anak kecil di sini dapat dipahami secara harfiah sebagai anak-anak kecil yang Yesus bicarakan dalam ayat 2 dan 4. Anak-anak dari jemaat yang percaya juga merupakan bagian dari keluarga besar-Nya sehingga mereka tidak boleh direndahkan, dihina dan bahkan diabaikan.

Secara kiasan, anak-anak kecil yang dimaksudkan di sini adalah orang-orang percaya yang lemah, jiwa mereka masih kecil seperti seorang anak, seperti anak-anak domba dalam kawanan yang digembalakan Kristus. ${ }^{23}$ Jelas anak-anak juga berharga di mata atau di hadapan Tuhan dan berhak untuk mendapat perlakuan yang sama sebagaimana yang diterima oleh orang dewasa. Demikian halnya dalam kehidupan gereja, gereja tidak boleh memandang anak dalam arti pelayanan anak sebagai sesuatu yang kecil atau tidak berarti sehingga kurang diperhatikan, karena bagaimanapun anak berharga dan bernilai bagi Tuhan.

\section{Malaikat di Sorga Mempedulikan Anak-anak}

Malaikat yang di sorga memperhatikan anak-anak artinya ini dikatakan oleh Kristus, dan kita boleh percaya akan perkataan-Nya, karena Dia datang dari sorga untuk memberitahukan kepada kita apa yang dilakukan di dunia malaikat di sana. Malaikatmalaikat Allah adalah malaikat-malaikat

\footnotetext{
${ }^{21}$ Hasan Sutanto, Perjanjian Baru Interlinear Yunani-Indonesia, Jilid I dan II (Jakarta: Lembaga Alkitab Indonesia, 2010), 439.

${ }^{22}$ Ibid., 522.

${ }^{23}$ Matthew Henry, Tafsiran Alkitab penuntun Hidup Berkelimpahan, diakses 5 Juni 2021. https://alkitab.sabda.org/commentary.php?book=49\&c hapter $=6 \&$ verse $=1 \#$ Wycliffe_2
}

pelindung dari anak-anak-Nya yang kecil. Malaikat-malaikat Allah adalah malaikat mereka juga, karena sesungguhnya segala yang menjadi milik Allah adalah juga milik kita, jika kita menjadi milik Kristus (1Kor. 3:22). Malaikat-malaikat Allah adalah milik orang-orang percaya, karena para malaikat itu ditugaskan untuk menjaga keselamatan mereka, menjaga tenda-tenda mereka dan melindungi mereka (Ibr. 1:14). Sebagian orang berpikir bahwa setiap orang kudus mempunyai malaikat pelindung. Tetapi, kita tidak perlu menduga-duga hal ini, karena kita yakin bahwa setiap orang kudus pasti akan selalu dilindungi oleh malaikat-malaikat Allah. Hal ini secara khusus terjadi dengan anak-anak-Nya yang kecil, karena merekalah yang paling lemah dan sering direndahkan. ${ }^{24}$ Mengenai hal ini, France berpendapat bahwa ini merupakan cara pembandingan yang sangat unik dimana Tuhan Yesus sedang mengatakan bahwa anak-anak kecil yang polos itu sama seperti malaikat-malaikat di surga yang memandang wajah Allah. ${ }^{25}$ Malaikat identik dengan kuasa dan kekuatan yang besar, tidak pernah identic dengan anak kecil, tetapi dalam hal ini Tuhan Yesus mengingatkan bahwa di hadapan Allah, para malaikat itu harus memandang wajah Bapa dan bersikap seperti seorang anak kecil yang rendah dan taat, bersikap seperti anak kecil yang polos. Hal ini menunjukkan bahwa anakanak tidak hanya berharga bagi Tuhan tetapi juga anak-anak dalam segala kepolosannya menjadi pembelajaran bagi orang dewasa dimana Tuhan Yesus sendiri memberikan gambaran yang jelas bagaimana malaikat

\footnotetext{
${ }^{24}$ Walter A. Elwell, Analisa topical terhadap Alkitab, diakses 8 Juni 2021. https://alkitab.sabda.org/commentary.php?book=49\&c hapter=6\&verse=1\#Matthew_Henry_4.

${ }^{25}$ R.T. France, The Gospel of Matthew, The New International Commentary on the New Testament (Grand Rapids, Michigan: Wm.B. Eerdmans Publishing, 2007), 687.
} 
bersikap seperti anak-anak dalam hubungan penyembahannya terhadap Allah Bapa.

\section{Bimbingan Anak Berpusat kepada Bapa}

Alkitab secara tegas menyatakan pentingnya anak dalam pengajaran, khususnya pengajaran mengenai Firman Tuhan sebagaimana perintah Tuhan yang dijelaskan dalam Perjanjian Lama untuk mendidik anakanak agar mereka sungguh mengenal dan taat kepada Bapa. Dalam hal ini orang tua/orang dewasa memainkan peranan mereka untuk membimbing anak mengenal Shema Israel. Dalam Ulangan 6:4-6 dituliskan bahwa Shema Israel diajarkan kepada anak-anak dalam berbagai kesempatan dan dengan berbagai cara. Selain itu Amsal 22:6 juga menegaskan agar umat Tuhan (orang percaya) yang dewasa mendidik orang muda sehingga pada masa tuanya tidak menyimpang dari jalan yang benar. Hal ini menunjukkan jika pendidikan/pengajaran/pembimbingan

(konseling) dalam hidup anak-anak menjadi bekal untuk kehidupan selanjutnya.

Hal yang sama juga ditegaskan dalam Matius 18:10 untuk tidak menganggap rendah anak-anak karena malaikat di surga juga mempedulikankan anak-anak.. menegaskan bahwa anak memiliki tempat yang penting dalam pandangan Allah sehingga anak-anak tidak boleh dianggap rendah, sebaliknya justru pada masa anak-anak inilah pendidikan, pengajaran atau pembimbingan (konseling) sangat penting. Sebagaimana telah dijelaskan sebelumnya bahwa dalam proses konseling anak, keterlibatan Allah merupakan hal yang sangat penting dimana peranan Tuhan Yesus sebagai Penasehat Ajaib menunjukkan keterbatasan manusia dalam menjalankan fungsi atau tugasnya. Sebagai konselor ia dapat membantu konseli menemukan akar persoalannya tetapi tidak dapat menyediakan kasih karunia untuk mengatasi kebiasaankebiasaan yang salah (dosa). Sama halnya dengan anak yang merupakan klien atau konseli, konselor juga adalah manusia yang membutuhkan kasih Allah sehingga dalam proses yang dilakukan seorang konselor memakai Alkitab sebagai dasar pelayanan yang dilakukan kepada anak-anak. Karena bagaimanapun pelayanan konseling menjadi salah satu cara untuk membawa anak menyadari posisi sebagai manusia berdosa yang memerlukan pemulihan dan keselamatan, maka dalam proses konseling anak yang dilakukan pertama-tama adalah adanya rekonsiliasi (pendamaian) diri sang anak dengan Allah (2 Kor. 5:20). Itu berati Alkitab mutlak diperlukan dalam proses konseling karena merupakan dasar yang tidak dapat ditawar-tawar lagi, dimana melaluinya anak dikenalkan pada pribadi Allah Bapa dan dalam hal ini pun penting bagi seorang konselor untuk menyadari tanggung jawabnya dimana konseling atau bimbingan yang dilakukan terhadap anak dalam konteks anak Sekolah Minggu adalah berpusat kepada Bapa dan bukan yang lain termasuk bukan pada kemampuan pribadi anak, orang tua anak dan sebagainya.

Berdasarkan penjelasan tersebut disimpulkan bahwa konseling anak berdasarkan Matius 18:10 adalah bahwa anak berharga di mata Tuhan, Malaikat memperdulikan Anak-anak, dan bimbingan Anak berpusat kepada Bapa. Dalam arti bahwa anak juga berharga di mata Tuhan dan berhak mendapat perlakuan yang sama sebagaimana yang diterima oleh orang dewasa, demikian halnya dalam kehidupan gereja, gereja tidak boleh memandang anak (pelayanan anak) sebagai sesuatu yang kecil, tidak berarti sehingga kurang diperhatikan karena anak berharga dan bernilai bagi Tuhan. Malaikat-malaikat Allah adalah milik orangorang percaya, karena para malaikat itu ditugaskan untuk menjaga keselamatan mereka, menjaga tenda-tenda mereka dan Jurnal Excelsis Deo: Jurnal Teologi, Misiologi dan Pendidikan |93 
melindungi mereka (Ibr. 1:14) Hal ini juga terjadi dengan anak-anak-Nya yang kecil, karena merekalah yang paling lemah dan sering direndahkan, namun dalam segala kepolosannya menjadi pembelajaran bagi orang dewasa dimana Tuhan Yesus sendiri memberikan gambaran yang jelas bagaimana malaikat bersikap seperti anak-anak dalam hubungan penyembahannya terhadap Allah Bapa. Dalam konseling anak, Alkitab mutlak diperlukan karena merupakan dasar yang tidak dapat ditawar-tawar lagi, dimana melaluinya anak dikenalkan pada pribadi Allah Bapa dan dalam hal ini pun penting bagi seorang konselor untuk menyadari tanggung jawabnya dimana konseling atau bimbingan yang dilakukan terhadap anak dalam konteks anak Sekolah Minggu adalah berpusat kepada Bapa.

\section{Keadaan Spiritual Anak Sekolah Minggu}

Gereja adalah tubuh Kristus selalu diperhadapkan dengan berbagai tantangan. Tantangan itu dari berbagai segi yakni dari dalam gereja sendiri, tetapi juga dari luar jemaat secara sekular. John Stott menuliskan dalam bukunya bahwa "Pada awal abad ke 21, kita diperhadapkan dengan berbagai tantangan yang membingungkan yang tidak pernah terbayangkan pada lima puluh tahun yang lalu". ${ }^{26}$ Itu berarti orang kristen harus melibatkan diri dan berusaha sungguhsungguh untuk berpikir secara Kristiani dalam menghadapi berbagai tantangan yang sedang dihadapi gereja baik secara individu maupun secara kolektif, baik orang dewasa maupun anak-anak. Gereja juga memperhatikan pelayanan konseling anak, dimana melalui layanan ini anak-anak akan lebih siap menghadapi tantangan zaman atau berbagai perubahan yang terjadi pada masa kini.
Anak-anak sebagai bagian dari jemaat gereja tentu mempunyai keperluan khusus yang menjadi tugas hamba-hamba Tuhan, majelis, pengurus gereja/jemaat dan para guru-guru di Sekolah Minggu. Berdasarkan beberapa pengamatan yang dilakukan oleh peneliti terhadap kondisi anak-anak, ditemukan: 1) Anak-anak SM lebih cenderung memahami lesson/kata pengantar dalam bahasa English sedangkan sumber/buku yg digunakan adalah dalam Bahasa Indonesia sehingga sulit berinteraksi atau mengadakan perbincangan dengan mereka. 2) Jangka perhatian yang pendek dimana ada anak-anak yang lemah/tidak dapat memberi tumpuan selama belajar/mengikut arahan dari guru, sering terganggu dengan keadaan sekitar karena tidak ada ruang khusus dan merasa bahwa mereka merasa dibebani dengan banyak pelajaran sekolah minggu. (pada masa yang sama, mereka juga perlu memberi perhatian kepada keperluan akademik). 3) Suka cari perhatian dari kedua orang tua juga guru SM. ${ }^{27}$

Meskipun demikian, harus dimengerti apa yang menyebabkan anak-anak tersebut cenderuang mencari perhatian atau mendapat perhatian. Sehubungan dengan hal ini pun, dari pengamatan yang dilakukan peneliti menyimpulkan beberapa alasan, antara lain: 1) Tidak mendapat perhatian yang cukup selama di rumah sehingga merasa kesepian serta ditinggalkan, 2) Terasa diabaikan karena orang tua terlalu sibuk dengan pekerjaan. ${ }^{28}$ Selain point-point di atas, peneliti juga menemukan fakta bahwa anak-anak lebih suka bermain dengan kawan-kawan daripada duduk belajar, anak-anak sibuk bermain dengan gadget (hp) sebelum memulai pelajaran dan harus dipanggil atau dikumpulkan jika akan memulai ibadah

${ }^{26}$ John Stott, Isu-isu Global (Jakarta: Yayasan ${ }^{28}$ Ibid.

${ }^{27}$ Hasil pengamatan yang dilakukan peneliti sebagai pelayan Sekolah Minggu. 
sekolah minggu. Selain itu ada juga anak yang ikut mood untuk hadir ibadah sekolah minggu, anak kurang menumpukan atau memusatkan perhatian pada pelajaran, tidak suka bertanya kerana malu, suka buat bising (keributan) ketika bersama kawan-kawan dan susah dikawal serta bercakap (berbicara) dengan kawan ketika guru sedang mengajar. ${ }^{29}$ Berdasarkan hasil pengamatan ini peneliti menyimpulkan bahwa dari sudut spritual, anak-anak sekolah minggu mungkin belum mengerti jika mereka seharusnya ada persiapan diri sebelum belajar kebenaran Firman Tuhan. Semuanya buat masa sekarang, dalam persediaan spiritual mereka, mereka memerlukan bimbingan dan peringatan dari guru-guru sekolah minggu, dalam berdoa, semasa memuji Tuhan, dalam penerapan pelajaran dan sebagainya. Dalam hal inilah peranan konseling sangat diperlukan untuk menolong anak-anak sehingga sejak dini mereka mengalami pertumbuhan iman di dalam Tuhan Yesus.Berdasarkan pemaparan di atas, peneliti menyimpulkan bahwa konseling anak berdasarkan Matius 18:10 ialah bahwa anak berharga dimata Tuhan itu sebabnya tidak boleh dianggap rendah karena anakpun punya hak yang sama dengan orang dewasa, para malaikat juga memperhatikan anak-anak bahkan dalam segi yang lain, perilaku anak dijadikan contoh bagaimana para malaikat bersikap dalam melayani Allah, selain itu bimbingan konseling yang dilakukan terhadap anak mutlak berpusat kepada Bapa itu sebabnya dalam hal ini, Alkitab adalah sumber atau dasar dalam bimbingan konseling yang dilakukan.

\section{Relevansi Konseling Anak berdasarkan Matius 18: 10 untuk Meningkatkan Spiritual Anak Sekolah Minggu}

\section{Anak-anak Sekolah Minggu berharga di Mata Tuhan}

Pengertian anak-anak kecil dalam teks Matius 18:10, dipahami secara harfiah sebagai anak-anak kecil yang Tuhan Yesus bicarakan sebelumnya dalam ayat 2 dan 4. Secara kiasan, anak-anak kecil yang dimaksudkan di sini adalah orang-orang percaya yang lemah, jiwa mereka masih kecil seperti seorang anak, seperti anak-anak domba dalam kawanan yang digembalakan Kristus. Sementara kalimat "jangan menganggap rendah" juga berarti jangan dihina atau diabaikan, ${ }^{30}$ memberi penegasan bahwa anak kecil juga patut diperhitungkan layaknya orang dewasa. Dengan demikian jika dihubungkan dengan konteks kehidupan gereja, maka jelas mengacu pada anak-anak dari jemaat yang disebut anak Sekolah Minggu sehingga mereka tidak boleh direndahkan dalam arti tidak boleh dibiarkan, diabaikan, melainkan mendapat perlakuan yang setara dengan orang dewasa termasuk didalamnya pemberian layanan konseling yang seringkali justru hanya diberikan kepada orang dewasa.

\section{Malaikat Memperdulikan Spiritual Anak- anak}

Ungkapan malaikat yang di sorga memperhatikan anak-anak pada dasarnya hal ini dikatakan oleh Tuhan Yesus, karena Dia datang dari sorga untuk memberitahukan kepada kita apa yang dilakukan di dunia malaikat di sana. Hendaknya dipahami bahwa malaikat-malaikat Allah adalah malaikatmalaikat pelindung dari anak-anak-Nya yang kecil, karena sesungguhnya segala yang menjadi milik Allah adalah juga milik kita, jika kita menjadi milik Kristus (1Kor. 3:22). Para malaikat ditugaskan untuk menjaga keselamatan orang percaya, menjaga tendatenda dan melindungi mereka (Ibr. 1:14). Hal

\footnotetext{
${ }^{29}$ Ibid.

${ }^{30}$ Hasan Sutanto, Perjanjian Baru Interlinear Yunani-Indonesia, Jilid I dan II, 439, 522. Jurnal Excelsis Deo: Jurnal Teologi, Misiologi dan Pendidikan |95
} 
ini juga tentu terjadi pada anak-anak-Nya kecil, karena mereka adalah bagian dari jemaat orang percaya yang paling lemah dan sering direndahkan. Malaikat identik dengan kuasa dan kekuatan yang besar, tidak pernah identic dengan anak kecil, tetapi dalam hal ini Tuhan Yesus mengingatkan bahwa di hadapan Allah, para malaikat itu harus memandang wajah Bapa dan bersikap seperti seorang anak kecil yang rendah dan taat, bersikap seperti anak kecil yang polos. Anak-anak tidak hanya berharga bagi Tuhan tetapi dalam segala kepolosannya mereka menjadi pembelajaran bagi orang dewasa dimana Tuhan Yesus sendiri memberikan gambaran yang jelas bagaimana malaikat bersikap seperti anakanak dalam hubungan penyembahannya terhadap Allah Bapa.

Dalam hubungannya dengan pelayanan konseling, jelas bahwa jika anak-anak Sekolah Minggu menunjuk pada pribadi yang paling lemah dan perlu dilindungi, maka sudah selayaknya jika gereja memberi perhatian khusus kepada anak tentu dalam konteks pelayanan anak Sekolah Minggu, sehingga mereka mengalami pertumbuhan iman yang baik, memiliki rasa percaya diri yang tinggi, merasa sebagai bagian yang diperlukan dalam ruang lingkup kehidupan jemaat (gereja), dengan demikian gereja melatih dan mempersiapkan anak-anak Sekolah Minggu sebagai generasi masa depan yang kuat, militant, dan generasi yang dapat diandalkan.

\section{Bimbingan Anak-anak Sekolah Minggu berpusat kepada Bapa}

Alkitab baik Perjanjian Lama maupun Perjanjian Baru menegaskan pentingnya anak dalam pengajaran, sebagaimana Ulangan 6:4-6 yang dikenal dengan Shema Israel dengan tujuan untuk mendidik anak-anak agar sungguh mengenal dan taat kepada Bapa. Dalam hal perlu peranan orang tua untuk mengajar anak-anak dalam berbagai kesempatan dan dengan berbagai cara. Amsal 22:6 juga menegaskan agar umat Tuhan/orang percaya yang dewasa mendidik orang muda sehingga pada masa tuanya tidak menyimpang dari jalan yang benar. Demikian halnya Matius 18:10 mengajarkan untuk tidak menganggap rendah anak-anak karena malaikat di surga juga mempedulikankan mereka, menegaskan bahwa anak memiliki tempat yang penting dalam pandangan Allah sehingga anak-anak tidak boleh dianggap rendah, atau direndahkan dalam arti tidak boleh dibiarkan, diabaikan, melainkan mendapat perlakuan yang setara dengan orang dewasa karena pada dasarnya justru pada masa anak-anak inilah pendidikan/pengajaran/pembimbingan (konseling) sangat penting. Dalam proses konseling yang dilakukan, konselor menyadari sepenuhnya bahwa keterlibatan Allah sebagai Penasehat Ajaib yang menunjukkan keterbatasan manusia dalam menjalankan fungsi atau tugasnya. Konselor dapat membantu konseli menemukan akar persoalannya tetapi tidak dapat menyediakan kasih karunia untuk mengatasi kebiasaan yang salah (dosa) sehingga seorang konselor harus menggunakan Alkitab sebagai dasar konseling anak dan membawa anak mengalami rekonsiliasi (pendamaian) dengan Allah (2 Kor. 5:20). Maka Alkitab mutlak diperlukan dalam proses konseling karena merupakan dasar yang tidak dapat ditawartawar lagi, dimana melaluinya anak dikenalkan pada pribadi Allah Bapa dan dalam hal ini pun penting bagi seorang konselor menyadari bahwa bimbingan konseling anak berpusat pada Allah.

Dalam hubungannya dengan konseling anak Sekolah Minggu, gereja hendaknya melatih dan mempersiapkan para guru Sekolah Minggu sehingga dapat menjalankan peranannya bukan hanya sebagai guru tetapi juga sebagai konselor anak 
Sekolah Minggu. Dengan demikian gereja hendaknya memiliki anggaran khusus terkait pelaksanaan pelatihan guru-guru Sekolah Minggu, selain itu ada baiknya jika guru-guru Sekolah Minggu diberi kesempatan untuk mengikuti studi teologi yang melaluinya diharapkan mereka mampu melaksanakan tugas dan fungsi sebagai guru Sekolah Minggu sekaligus Konselor anak dengan baik dengan pemahaman theologi yang benar dan dapat dipertanggungjawabkan. Selain itu gereja harus melakukan dan memberi perhatian yang seimbang terhadap pelayanan anak Sekolah Minggu tempat dimana mereka mendapatkan pelayanan tersendiri serta melibatkan orang tua dalam proses pendampingan terhadap anak dimana mereka memiliki waktu yang lebih lama dengan anak dibanding guru sekolah minggu yang hanya satu kali bertemu dalam kelas Sekolah Minggu.

Dengan demikian jelas bahwa proses konseling anak Sekolah Minggu yang dilakukan, konselor menyadari sepenuhnya bahwa keterlibatan Allah sebagai Penasehat Ajaib yang menunjukkan keterbatasan manusia dalam menjalankan fungsi atau tugasnya. Konselor dapat membantu konseli menemukan akar persoalannya tetapi tidak dapat menyediakan kasih karunia untuk mengatasi kebiasaan yang salah (dosa) sehingga seorang konselor harus menggunakan Alkitab sebagai dasar konseling anak dan membawa anak mengalami rekonsiliasi/pendamaian dengan Allah (2 Kor. 5:20). Maka Alkitab mutlak diperlukan dalam proses konseling karena merupakan dasar yang tidak dapat ditawar-tawar lagi, dimana melaluinya anak dikenalkan pada pribadi Allah Bapa dan dalam hal ini pun penting bagi seorang konselor menyadari bahwa bimbingan konseling anak berpusat pada Allah sehingga secara tidak langsung melatih anak untuk hidup dalam kebergantungan kepada Allah.

\section{KESIMPULAN}

Konseling anak berdasarkan Matius 18:10 ialah bahwa anak berharga di mata Tuhan, Mailakat-malaikat memperdulikan Anak-anak, dan Bimbingan Anak berpusat kepada Bapa. Dalam konteks jemaat, anakanak tidak boleh direndahkan dalam arti tidak boleh dibiarkan, diabaikan, melainkan mendapat perlakuan yang setara dengan orang dewasa termasuk didalamnya pemberian layanan konseling yang seringkali justru hanya diberikan kepada orang dewasa. Gereja harus melakukan dan memberi perhatian yang seimbang terhadap pelayanan anak Sekolah Minggu tempat dimana mereka mendapatkan pelayanan tersendiri.

Dalam proses konseling yang dilakukan, konselor menyadari sepenuhnya bahwa keterlibatan Allah sebagai Penasehat Ajaib yang menunjukkan keterbatasan manusia dalam menjalankan fungsi atau tugasnya. Konselor dapat membantu konseli menemukan akar persoalannya tetapi tidak dapat menyediakan kasih karunia untuk mengatasi kebiasaan yang salah (dosa) sehingga seorang konselor harus menggunakan Alkitab sebagai dasar konseling anak dan membawa anak mengalami rekonsiliasi (pendamaian) dengan Allah (2 Kor. 5:20). Maka Alkitab mutlak diperlukan dalam proses konseling karena merupakan dasar yang tidak dapat ditawartawar lagi, dimana melaluinya anak dikenalkan pada pribadi Allah Bapa dan dalam hal ini pun penting bagi seorang konselor menyadari bahwa bimbingan konseling anak berpusat kepada Allah.

\section{DAFTAR PUSTAKA}

Beek, Aart van. Pendampingan Pastoral. Jakarta: BPK Gunung Mulia, 2007.

Collins, Gary R. Pengantar Pelayanan Konseling Kristen yang Efektif. Malang: Seminari Alkitab Asia 
Elwell A. Walter, Analisa topical terhadap Alkitab, diakses 8 Juni 2021. https://alkitab.sabda.org/commentary. php? book $=49 \&$ chapter $=6 \&$ verse $=1 \#$ Matthew_Henry_4.

France, R.T. The Gospel of Matthew, The New International Commentary on the New Testament. Grand Rapids, Michigan: Wm. B. Eerdmans Publishing, 2007.

Geldard, Kathryn. Konseling Anak-anak Panduan Praktis Edisi ketiga. Yogyakarta: Pustaka Pelajar, 2011.

Ginting, E.P. Gembala dan Konseling Pastoral. Yogyakarta: Andi, 2002.

GP, Harianto. Teologi Pastoral. Yogyakarta: Andi, 2020.

Henry, Matthew. Tafsiran Alkitab penuntun Hidup Berkelimpahan, diakses 5 Juni 2021.

https://alkitab.sabda.org/commentary. php? book $=49 \&$ chapter $=6 \&$ verse $=1 \#$ Wycliffe_2.

Latipun. Psikologi Konseling. Malang: UMM Press, 2015.

Luwis Bin, Render. Pembinaan Spiritual Jemaat Gereja. Bandung: Agiamedia, 2021.

Nazir, Mohamad. Metode Penelitian. Jakarta: Ghalia Indonesia, 1988.

Oates, Wayne E. Pastoral Counseling. Philadelfia: The Westminster Press, 1974.

Pasang, Agustina. Materi Seminar Konseling dan Pelayanan Konseling. Balikpapan: GMII Filadelfia, 2012.

Prayitno \& Amti Erman. Dasar-dasar Bimbingan dan Konseling. Jakarta: Rineka Cipta, 2015.

R, Thantawy. Kamus Istilah Bimbingan dan Konseling. Jakarta: Gramedia, 2005.

Rahmania, Lativani. "Wajah Baru Bimbingan Konseling di Era Postmodern", diakses 27 Mei 2021, www.kompasiana.com $>$ humaniora $>\mathrm{e}$ dukasi.

Saleh, Adnan Achiruddin. Pengantar Psikologi. Makasar: Aksara Timur, 2018.

Stott, John. Isu-isu Global. Jakarta: Yayasan Komunikasi Bina Kasih/OMF, 2015.

Sutanto, Hasan. Perjanjian Baru Interlinear Yunani-Indonesia, Jilid I dan II. Jakarta: Lembaga Alkitab Indonesia, 2010.

Therisnajaya, Kay. "Konseling Anak", Konselinganak.com, diakses tanggal 24 Mei 2021, https://www.konselinganak.com/.

Tjandrarini, Kristina. Bimbingan Konseling Keluarga. Salatiga: Widya Sari Press, 2004. 